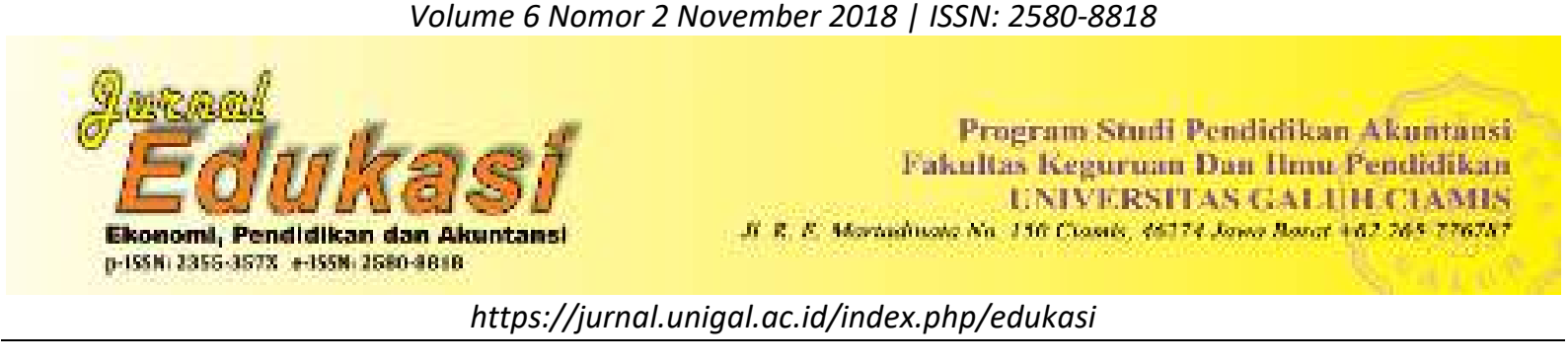

\title{
ANALISIS PERPUTARAN PIUTANG DALAM MENINGKATKAN SHU KPRI MEKAR BARAT
}

\author{
Oleh: \\ Yuyun Susanti \\ Program Studi Pendidikan Akuntansi Universitas Galuh, Indonesia \\ Email: yuyunsusanti444@gmail.com \\ Sejarah Artikel: Diterima September 2018, Disetujui Oktober 2018, Dipublikasikan November 2018
}

\begin{abstract}
ABSTRAK
Usaha koperasi merupakan gerakan ekonomi kerakyatan dengan asas kekeluargaan dan mementingkan kesejahteraan anggotanya, seperti tertuang dalam Pasal 33 Ayat 1 Undang- Undang Dasar 1945 yang berbunyi, "Perekonomian disusun sebagai usaha bersama berdasar atas asas kekeluargaan". Koperasi merupakan satu-satunya bentuk usaha yang paling sesuai dengan demokrasi ekonomi dan selaras dengan semangat dan jiwa gotong royong Bangsa Indonesia. Koperasi memiliki beberapa prinsip yang diantaranya adalah keanggotaan bersifat suka rela dan terbuka, pengelolaan dilaksanakan secara demokratis, pembagian Sisa Hasil Usaha (SHU) dilakukan secara adil sebanding dengan besarnya jasa usaha masing-masing anggota, pemberian balas jasa yang terbatas terhadap modal, serta kemandirian. Prinsip-prinsip pengelolaan koperasi tersebut menjadi keunggulan koperasi dibandingkan badan usaha lainnya apabila diterapkan dengan benar. Sebagai salah satu pelaku ekonomi, koperasi diharapkan mampu menjadi sokoguru perekonomian Indonesia. Hasil penelitian dapat di jelaskan sebagai berikut: Pertama; Perputaran piutang pada KPRI Mekar Barat Sadananya Kabupaten Ciamis selama 5 tahun yaitu, tahun 2014 sebanyak 1,61 kali, 2015 sebanyak1,67 kali, tahun 2016 sebanyak 1,57 kali, tahun 2017 sebanyak 1,21 kali dan tahun 2018 sebanyak 1,11 kali, hal ini berarti perputaran piutang pada koperasi Mekar Barat sudah baik, dan waktu perputaran piutang relatif cepat. Kedua; Besarnya peningkatan laba usaha pada KPRI Mekar Barat Sadananya Kabupaten Ciamis untuk waktu 5 tahun yaitu tahun 2014 SHU sebesar 29.100.000, pada tahun 2015 sebesar 11.000.000, pada tahun 2016 sebesar 23.169.426, pada tahun 2017 sebesar 27.142.000, dan pada tahun 2018 sebesar 44.798.000. Pada tahun terakhir mengalami kenaikan SHU 33,13\% berarti koperasi tersebut lebih baik dari tahun sebelumnya cara mengelola usahanya terutama dalam pengelolaan piutang anggota. Ketiga; Besarnya peranan perputaran piutang dalam meningkatkan laba pada KPRI Mekar Barat Sadananya Kabupaten Ciamis yaitu 37,68 \% sedangkan $62,32 \%$ peranan diberikan oleh faktor lain.
\end{abstract}

Kata Kunci: Usaha Koperasi, Perputaran Piutang dan Sisa Hasil Usaha

\section{PENDAHULUAN}

Koperasi merupakan badan usaha yang kegiatannya bertujuan untuk meningkatkan kesejahtraan para anggotanya yaitu dengan memperoleh laba atau sisa hasil usaha (SHU) yang optimal. Menurut (Sjamsyuri, $2002: 1$ ) bahwa kriteria koperasi yang baik yaitu "koperasi yang dapat menggarap dua fungsi sekaligus yaitu fungsi bisnis dan fungsi sosial serta manfaat koperasi dapat dirasakan baik oleh para anggotanya, masyarkat sekitar dan juga oleh pemerintah". Pada koperasi yang bergerak dalam usaha simpan pinjam piutang merupakan aset yang dominan dan menempati proporsi yang besar di dalam neraca.

Piutang timbul karena adanya kebijakan dalam penjualan kredit. Pemberian kredit tidak akan segera menjadi penerimaan kas, tetapi melalui proses jamgka waktu berdasarkan perjanjian. Oleh karena itu penting artinya untuk menetapkan kebijakan kredit yang efektif dan prosedur-prosedur penagihan piutang untuk menjamin pembayaran piutang tepat pada waktunya dan menghindari kerugian piutang tak tertagih. Semakin besar piutang suatu perusahaan tersebut harus selalu diwaspadi oleh 
manajemen agar tidak kesulitan dalam menagih piutangnya kembali. Makin tinggi perputaran piutang berarti makin besar penerimaan kas yang akan diputarkan kembali. Dengan demikian maka besar pengaruhnya terhadap penerimaan laba (SHU). Hal ini sejalan dengan pendapat Munawir (2004 : 75) mengenai tingkat perputaran piutang, sebagai berikut : "makin tinggi ratio (turn over) menunjukan modal kerja yang ditanamkan dalam pitang rendah, sebaliknya kalau ratio semakin rendah berarti ada over investment dalam piutang sehingga memerlukan analisa lebih lanjut".

Berdasarkan uraian di atas nampak keterhubungan antara perputaran piutang dengan laba (SHU). Fokus masalahnya adalah apakah perputaran piutang berperan dalam meningkatkan laba usaha pada KPRI Mekar Barat? Hal tersebut menarik penulis untuk meneliti lebih dalam di KPRI Mekar Barat Sadananya Kabupaten Ciamis. Sebagai data awal di sajikan pada tabel sebagai berikut :

Tabel 1

KPRI "Mekar Barat"

Neraca

Periode 2014-2018

\begin{tabular}{llrrrr}
\multirow{2}{*}{ No Nama perkiraan } & \multicolumn{5}{c}{ Tahun } \\
\cline { 2 - 6 } & \multicolumn{1}{c}{2014} & \multicolumn{1}{c}{2015} & \multicolumn{1}{c}{2016} & \\
\hline 1. & Aktiva & & & & \\
& Aktiva Lancar : & & & & \\
Kas & $5.852 .502,-$ & $5.330 .512,-$ & $2.485 .897,-$ & $25.542 .203,-$ & $24.073 .228,-$ \\
Bank & $22.125 .940,-$ & $433.500 .979,-$ & $19.220 .000,-$ & $96.815 .326,-$ & $91.810 .585,-$ \\
Piutang & $242.267 .110,-$ & $467.315 .010,-$ & $1.163 .837 .940,-$ & $1.543 .441 .230,-$ & $1.751 .276 .880,-$ \\
Jumlah aktiva lancar & $270.245 .552,-$ & $516.146 .501,-$ & $1.185 .543 .837,-$ & $1.665 .798 .759,-$ & $1.867 .160 .693,-$ \\
Penyertaan : & & & & & \\
Simpanan da PKPPRI & $14.969 .549,98$ & $17.357 .149,98$ & $19.157 .149 .98,-$ & $19.157 .149 .98,-$ & $21.577 .499,98$ \\
Saham SKP-B-IKPRI & $1.191 .200,-$ & $1.191 .200,-$ & $1.191 .200,-$ & $1.191 .200,-$ & $1.191 .200,-$ \\
Jumlah aktiva tetap & $16.160 .749,98$ & $18.548 .394,98$ & $20.348 .349,98$ & $20.348 .349,98$ & 22.768 .749 .98 \\
Aktiva Tetap : & & & & & \\
Tanah & $5.501 .000,-$ & $5.501 .000,-$ & $5.501 .000,-$ & $5.501 .000,-$ & $5.501 .000,-$ \\
Bangunan & $28.698 .325,-$ & $28.698 .325,-$ & $28.698 .325,-$ & $28.698 .325,-$ & $28.698 .325,-$ \\
Peralatan & $2.899 .025,-$ & $2.899 .025,-$ & $2.886 .025,-$ & $2.886 .025,-$ & $2.886 .025,-$ \\
Jumlah aktiva tetap & $37.098 .350,-$ & $37.098 .350,-$ & $37.098 .350,-$ & $37.098 .350,-$ & $37.098 .350,-$ \\
Aktiva Lain-lain : & & & & & \\
Sisa barang & $566.500,-$ & $566.500,-$ & $566.500,-$ & $566.500,-$ & $566.500,-$ \\
Rugi & $86.320 .048,19$ & $86.620 .048,19$ & $86.620 .048,19$ & $86.620 .048,19$ & $86.620 .048,19$ \\
Jumlah aktiva lain-lain & $86.886 .548,19$ & $86.886 .548,19$ & $86.886 .548,19$ & $86.886 .548,19$ & $86.886 .548,19$ \\
JUMLAH AKTIVA & $410.390 .800,17$ & $658.679 .749,17$ & $1.331 .377 .085,17$ & $1.811 .367 .007,17$ & $2.013 .914 .341,17$
\end{tabular}

2 Putang :

\section{Hutang ke PKPPRI}

Tabungan Murid

Titipan pihak ke 3

Hutang ke BKE

Hutanh ke BMI

Dana-dana

Jumlah Hutang

Modal :

Simpanan Pokok

Simpanan Wajib

Simp. Manasuka

Dana Cadangan

Simp.Gerkop

Dana Gedung

Dana Resiko

SHU

Jumlah

JUMLAH PASIVA

$3.773 .701,-$
$77.946371,-$
$29.007 .000,^{-}$
$86.768400,-$
-
$939.727,26$
$198.435 .199,26$

$5.505 .000,-$
$162.900 .050,-$
$2.253 .500,-$
$2.563 .000,-$
$3.798 .500,-$
$760.000,-$
$5.075 .550,91$
$29.100 .000,-$
$211.955 .600,91$
410.390 .800 .17

25.000.000,77.946.371,25.167.000,300.000.000,-

$939.727,26$ 429.053.098,26

$5.550 .000,-$ 186.330.600,-

7.683.000,-

5.563.000,-

5.664.500,-

1.699.727,-

7.075.550,91

11.000.000,-

$230.566 .378,17$ $658.679 .749,17$
17.500.000,77.946.371,20.767.000,133.772.260,-

797.500.000,1.045.485.631,-

5.500.000,222.400.500,

7.624.250,-

7.213.000,-

7.659.000,$1.699 .727,26$

$10.625 .550,91$

23.169.426,-

$285.891 .454,17$

1.331.377.085, 17
77.946.371,-

15.227.000,-

674.646.818,692.071.290,-

1.459.891.479,-

5.475.000,296.389.000,8.024.250,-

12.438.000,-

11.685.000,$1.699 .727,26$ 15.625.550,91 27.142.000,351.475.528, $1.811 .367 .007,17$
77.946.371,8.727.000,1.244.450.179,253.378.400,-

1.584.501.950,-

$5.600 .000,-$

$316.375 .600,-$

8.024.250,-

16.509.300,-

15.779.500,1.699.727.26,20.626.013,91

44.798.000,-

$429.412 .391,17$ 2.013.914.341,17

Sumber : KPRI Mekar Barat, 2018 


\begin{tabular}{|c|c|c|c|c|c|c|}
\hline \multirow[b]{2}{*}{ No } & \multicolumn{6}{|c|}{$\begin{array}{l}\text { Tabel } 2 \\
\text { KPRI "Mekar Barat" } \\
\text { Laporan Laba/Rugi } \\
\text { Periode 2014-2018 }\end{array}$} \\
\hline & Uraian Perkiraan & 2014 & 2015 & 2016 & 2017 & 2018 \\
\hline 1. & $\begin{array}{l}\text { Pendapatan : } \\
\text { 1. Jasa dan Usaha Kredit Uang, } \\
\text { Provisi dan keuntungan lain- } \\
\text { lain } \\
\text { 2. Jasa dari PKP-RI, Jasa PKP- }\end{array}$ & $\begin{array}{r}70.400 .000,- \\
1.450 .000,- \\
650.000\end{array}$ & $\begin{array}{r}74.605 .165,- \\
1.500 .000,- \\
700.000,-\end{array}$ & $\begin{array}{r}138.673 .703,- \\
1.536 .500,- \\
-\end{array}$ & $\begin{array}{r}311.830 .311,- \\
1.526 .620,- \\
-\end{array}$ & $\begin{array}{r}264.042 .380,- \\
1.700 .000,- \\
1.200 .000,\end{array}$ \\
\hline & Jumlah Pendapatan & $72.500 .000 .-$ & $76.805 .165 .-$ & 140.210 .203 & $313.356 .931 .-$ & $266.942 .380 .-$ \\
\hline 2. & $\begin{array}{l}\text { Biaya-biaya : } \\
\text { 1. Upah pungut } \\
\text { 2. Administrasi } \\
\text { 3. Biaya Pengawas } \\
\text { 4. Upah Pengurus } \\
\text { 5. Ongkos Jalan Pengurus } \\
\text { 6. Jasa ke BKE } \\
\text { 7. Biaya Rapat-rapat Organisasi } \\
\text { 8. Jasa ke PKP-RI Ciamis } \\
\text { 9. Operasionol Kantor Dinas } \\
\text { 10. Beban Sosial } \\
\text { 11. Iuran Dekopinda } \\
\text { 12. Dana Sakit } \\
\text { 13. Jasa pada pihak ke } 3 \\
\text { 14. Sodakoh } \\
\text { 15. Honor Pegawai } \\
\text { 16. Operasional + Transper ke } \\
\text { BKE } \\
\text { 17. Dana Resiko } \\
\text { 18. Lain-lain }\end{array}$ & $\begin{array}{r}150.000,- \\
500.000,- \\
300.000,- \\
425.000,- \\
900.000,- \\
23.475 .000,-- \\
9.970 .000,- \\
2.025 .000,-- \\
1.250 .000,- \\
400.000,-- \\
60.000,- \\
280.000,- \\
1.000 .000,- \\
125.000,- \\
400.000,- \\
240.000,- \\
1.000 .000,- \\
900.000,- \\
43.400 .000,-\end{array}$ & $\begin{array}{r}180.000,- \\
540.000,- \\
300.000,- \\
450.000,- \\
900.000,- \\
37.262 .640,- \\
14.157 .201,- \\
3.603 .250,- \\
2.002 .065,- \\
475.000,- \\
60.000,- \\
340.000,- \\
2.435 .000,- \\
175.000,- \\
480.000,- \\
240.000,- \\
1.000 .000,- \\
1.205 .000,- \\
65.805 .156,-\end{array}$ & $\begin{array}{r}680.000,- \\
1.265 .000,- \\
300.000,- \\
1.500 .000,- \\
900.000,- \\
43.238 .979,- \\
19.875 .000,- \\
6.120 .000,- \\
1.380 .000,- \\
1.050 .000,- \\
540.000,- \\
650.000,- \\
1.800 .000,- \\
225.000,- \\
25.500 .000,- \\
240.000,- \\
5.000 .000,- \\
6.776 .448,- \\
117.040 .777,-\end{array}$ & $\begin{array}{r}480.000,- \\
678.000,- \\
450.000,- \\
900.000,- \\
750.000,- \\
66.332 .000,- \\
18.286 .350,- \\
2.136 .250,- \\
847.250,- \\
580.450,- \\
268.000,- \\
175.000,- \\
1.246 .020,- \\
635.000,- \\
170.250 .398,- \\
16.514 .750,- \\
5.000 .463,- \\
684.500,- \\
286.214 .931,-\end{array}$ & $\begin{array}{r}- \\
- \\
1.280 .000,- \\
1.350 .000,- \\
2.750 .000,- \\
125.346 .602,- \\
28.350 .000,- \\
- \\
1.200 .000,- \\
1.150 .000,- \\
320.000,- \\
2.485 .000,- \\
847.846,- \\
280.000,- \\
33.744 .398,- \\
10.500 .000,- \\
5.000 .534,- \\
7.540 .000,- \\
222.144 .380,-\end{array}$ \\
\hline & SHU / Laba & $000,-$ & $000,-$ & $23.169 .429,-$ & $27.142 .000,-$ & 44.942.380,- \\
\hline
\end{tabular}

Sumber : KPRI Mekar Barat, 2018

Tabel di atas menunjukan bahwa, besarnya piutang pada KPRI Mekar Barat dari tahun ke tahun mengalami kenaikan, sebagai contoh pada tahun 2014 besarnya piutang sebesar Rp 242.267.110,- dan SHU sebesar Rp 29.100.000,-. Pada tahun 2015 besarnya piutang sebesar Rp 467.315.010,- menunjukan bahwa adanya kenaikan sebesar Rp 225.047.900,-, (Rp 467.315.010,- dikurangi Rp 242.267.110,-), kenaikan ini terjadi setiap tahun sampai dengan tahun 2018. Sedangkan SHU pada tahun 2013 sebesar Rp 29.100.000,- dan pada tahun 2015 sebesar Rp 11.000.000,-, dari data tersebut SHU mengalami penurunan sebesar Rp 18.100.000,(Rp 29.100.000,- dikurangi Rp 11.000.000,-). Penurunan SHU ini terjadi sampai dengan tahun 2017, dan nilai nominalnya tidak sebanding dengan tahun 2014.

Dari uraian tersebut penulis berasumsi bahwa, piutang pada KPRI "Mekar Barat" dari tahun ketahun mengalami kenaikan sampai tahun 2018, tetapi dengan besarnya kenaikan piutang tidak berpengaruh pada besarnya SHU, sampai pada tahun 2017. Dari data di atas, sekaligus penulis jadikan masalah utama untuk dijadikan bahan pemikiran yang akan diteliti penyebab masalah tersebut.

\section{METODE PENELITIAN}

Penelitian merupakan suatu usaha untuk dapat menemukan kebenaran yang objektif sebagai pegangan untuk memecahkan masalah yang sedang diteliti. Untuk tujuan ini, maka peneliti harus dapat memilih metode yang paling tepat sesuai dengan tujuan yang ingin dicapai. Hal ini sesuai dengan pendapat Sugiyono (2011:15) "penelitian desktiptif adalah sebuah penelitian yang bertujuan untuk memberikan atau menjabarkan suatu keadaan atau fenomena yang terjadi saat ini dengan menggunakan prosedur ilmiah untuk menjawab masalah secara aktual". Arikunto (2010:3) bahwa: "Penelitian Deskriptif adalah penelitian yang dimaksudkan untuk menyelidiki keadaan, kondisi atau hal-hal 
lain yang sudah disebutkan, yang hasilnya dipaparkan dalam bentuk laporan penelitian. Peneliti tidak mengubah, menambah, atau mengadakan manipulasi terhadap objek atau wilayah penelitian. Peneliti hanya memotret apa yang terjadi pada diri objek atau wilayah yang diteliti, kemudian memaparkan apa yang terjadi dalam bentuk laporan penelitian secara lugas, seperti apa adanya.

\section{HASIL PENELITIAN DAN PEMBAHASAN}

Penjualan kredit dan piutang pada koperasi KPRI Mekar Barat Sadananya Ciamis, disajikan dalam tabel sebagai berikut:

Tabel 3

Penjualan Kredit dan Piutang

Pada koperasi KPRI Mekar Barat Sadananya Ciamis

Periode tahun 2014-2018

\begin{tabular}{crrr} 
Tahun & Penjualan kredit tahun $(\mathrm{Rp})$ & Piutang awal tahun $(\mathrm{Rp})$ & Piutang akhir tahun $(\mathrm{Rp})$ \\
\hline 2014 & 242.267 .110 & 134.820 .000 & 166.341 .000 \\
2015 & 467.315 .010 & 166.341 .600 & 392.189 .500 \\
2016 & 1.163 .837 .940 & 392.189 .500 & 1.085 .560 .000 \\
2017 & 1.543 .441 .230 & 1.085 .560 .000 & 1.466 .211 .290 \\
2018 & 1.751 .276 .880 & 1.466 .211 .290 & 1.677 .596 .940 \\
\hline Jumlah & 5.168 .138 .170 & 3.245 .122 .390 & 4.787 .898 .730
\end{tabular}

Berdasarkan tabel di atas dapat diketahui bahwa baik penjualan kredit maupun piutang dari tahun ke tahun mengalami peningkatan hal ini disebabkan antara lain oleh bertambahnya jumnlah anggota dan jumlah simpanan serta tingkat perputaran piutang yang meningkat dari tahun ke tahun. Untuk lebih jelasnya mengenai tingkat perputaran piutang pada Koperasi KPRI Mekar Barat Sadananya Ciamis, diuraikan sebagai berikut:

1. Tingkat perputaran pitang tahun 2014

Rata-rata piutang = saldo awal tahun + saldo akhir tahu

$$
=\frac{134.820 .000+166.341 .600}{2}
$$$$
=150.580 .800
$$

Perputaran piutang $\quad=$ Penjualan kredit netto

$$
\text { Rata-rata piutang }
$$

$$
\begin{aligned}
& =\frac{242 \cdot 267 \cdot 110}{150 \cdot 580 \cdot 800} \\
& =1,61
\end{aligned}
$$

Rata-rata/periode pengumpulan piutang $\quad=\underline{360 \times \text { rata-rata piutang }}$

$$
\text { Penjualan kredit }
$$

$$
\begin{aligned}
& =\frac{360 \times 150.580 .800}{242.267 .110} \\
& =223,76
\end{aligned}
$$

2. Tingkat perputaran piutang tahun 2015

Rata-rata piutang

$$
\begin{aligned}
& =\frac{\text { saldo awal tahun }+ \text { saldo akhir tahun }}{2} \\
& =\frac{166.341 .600+392.189 .500}{2} \\
& =279.265 .550
\end{aligned}
$$


Perputaran piutang $\quad=$ Penjualan kredit netto

Rata-rata piutang

$$
\begin{aligned}
& =\frac{467.315 \cdot 010}{279.265 .550} \\
& =1,67
\end{aligned}
$$

Rata-rata/periode pengumpulan piutang $\quad=\underline{360 \times \text { rata-rata piutang }}$

$$
\begin{aligned}
& \text { Penjualan kredit } \\
& =\frac{360 \times 279.265 .550}{467.315 .010}
\end{aligned}
$$$$
=215,13
$$

3. Tingkat perputaran piutang tahun 2016

Rata-rata piutang = saldo awal tahun + saldo akhir tahun

$$
\begin{aligned}
& =\frac{392.189 .500+1.085 .560 .000}{2} \\
& =738.874 .750
\end{aligned}
$$

Perputaran piutang $=\underline{\text { Penjualan kredit netto }}$

$$
\begin{aligned}
& \text { Rata-rata piutang } \\
& =\frac{1.163 .837 .940}{738.874 .750} \\
& =1,57
\end{aligned}
$$

Rata-rata/periode pengumpulan piutang $\quad=\underline{360 \times \text { rata-rata piutang }}$ Penjualan kredit

$$
=\frac{360 \times 738.874 .750}{1.163 .837 .940}
$$

$$
=228,55
$$

4. Tingkat perputaran piutang tahun 2017

Rata-rata piutang $=\underline{\text { saldo awal tahun }+ \text { saldo akhir tahun }}$

$$
\begin{aligned}
& =\frac{1.085 .560 .000+1.466 .211 .290}{2} \\
& =1.275 .885 .645
\end{aligned}
$$

Perputaran piutang $=\underline{\text { Penjualan kredit netto }}$

$$
\text { Rata-rata piutang }
$$

$$
\begin{aligned}
& =\frac{1.543 .441 .230}{1.275 .885 .645} \\
& =1,21
\end{aligned}
$$

Rata-rata /periode pengumpulan piutang $\quad=360 \times$ rata-rata piutang Penjualan kredit

5. Tingkat perputaran piutang tahun 2018

$$
\begin{aligned}
& =\frac{360 \times 1 \cdot 275 \cdot 885 \cdot 645}{1 \cdot 543 \cdot 441 \cdot 230} \\
& =297,56
\end{aligned}
$$




$$
\begin{aligned}
& \text { Rata-rata piutang = } \underline{\text { saldo awal tahun }+ \text { saldo akhir tahun }} \\
& =\frac{1.466 .211 .290+1.677 .596 .940}{2} \\
& =1.571 .904 .115 \\
& \text { Perputaran piutang }=\text { Penjualan kredit netto } \\
& \text { Rata-rata piutang } \\
& =\frac{1.751 .276 .880}{1.571 .904 .115} \\
& =1,11 \\
& =\frac{360 \times 1.571 .904 .115}{1.751 .276 .880} \\
& =323,13
\end{aligned}
$$
ini:

Berdasarkan hasil perhitungan di atas, jika dimasukan kedalam tabel akan terlihat seperti dibawah

Tabel 4

Hasil perhitungan perputaran piutang dan periode pengumpulan piutang

\begin{tabular}{lcc} 
Tahun & Perputaran piutang & Periode pengumpulan piutang \\
\hline 2014 & $1,61 \mathrm{kali}$ & 223.76 \\
2015 & $1,67 \mathrm{kali}$ & 215,13 \\
2016 & $1,57 \mathrm{kali}$ & 228,55 \\
2017 & $1,21 \mathrm{kali}$ & 297,56 \\
2018 & $1,11 \mathrm{kali}$ & 323,13
\end{tabular}

Berdasarkan tabel di atas dapat dijelaskan bahwa rata-rata pengumpulan piutang pada koperasi KPRI Mekar Barat Sadananya Ciamis untuk 5 tahun kurang dari 360 hari (satu tahun) sedangkan batas waktu pinjaman maksimal satu tahun, ini berarti dibawah standar dari yang ditetapkan Koperasi KPRI Mekar Barat Sadananya Ciamis. Dengan demikian maka resiko kredit Koperasi KPRI Mekar Barat Sadananya Ciamis kemungkinan sangat kecil terjadi, hal ini dikarenakan banyak anggota/nasabah yang lunas sebelum jatuh tempo.

\section{Laba/SHU yang dicapai KPRI Mekar Barat}

Untuk mengetahui Sisa Hasil Usaha dan perubahan naik turunnya selama kurun waktu lima tahun dari 2014 sampai dengan 2018, berikut disajikan dalam tabel dibawah ini:

Tabel 5

Laba/rugi selama lima tahun KPRI Mekar Barat Periode 2014-2018

(dalam rupiah)

\begin{tabular}{cccc} 
Tahun & SHU/laba & $\%$ & Perubahan naik/turun \\
\hline 2014 & 29.100 .000 & 21,52 & - \\
2015 & 11.000 .000 & 8,14 & $-13,38$ \\
2016 & 23.169 .426 & 17,14 & +9 \\
2017 & 27.142 .000 & 20,07 & $+2,93$ \\
2018 & 44.798 .000 & 33,13 & $+13,06$
\end{tabular}

Berdasarkan tabel di atas dapat dijelaskan bahwa besar Sisa Hasil Usaha dari tahun ke tahun mengalami kenaikan, kecuali pada tahun 2014 ke tahun 2015, mengalami penurunan sebesar $(-13,38)$, tetapi pada tahun berikutnya mengalami kenaikan hingga tahun 2018 dengan nominal pendapatan 
sebesar Rp 44.798.000,- dibandingkan pada tahun sebelumnya, maksimal jumlah laba sebesar Rp 29.100.000,-

Untuk mengetahui perputaran piutang serta SHU yang diperoleh koperasi Mekar Barat, berikut tabel 4.4 dibawah ini.

Tabel 6

Perputaran Piutang dan jumlah SHU yang dicapai KPRI Mekar Barat

Dari periode tahun 2014-2018

\begin{tabular}{cccc} 
Tahun & Perputaran piutang & Laba/SHU & Pembulatan perhitungan SHU \\
\hline 2014 & 1,61 & 29.100 .000 & 29,10 \\
2015 & 1,67 & 11.000 .000 & 11,00 \\
2016 & 1,57 & 23.169 .426 & 23,17 \\
2017 & 1,21 & 27.142 .000 & 27,14 \\
2018 & 1,11 & 44.798 .000 & 44,80
\end{tabular}

Berdasarkan tabel di atas dapat dijelaskan bahwa perputaran piutang berperan dalam meningkatkan laba usaha. Perputaran piutrang pada tahun 2014 sebesar 1,61 dengan laba SHU 29.10 begitu pula pada tahun berikutnya perputaran piutang semakin kecil yaitu sebesar 1,11 kali dengan laba usaha pada koperasi sebesar 44,80. Dengan demikian penulis berasumsi bahwa perputaran piutang berperan dalam meningkatkan SHU pada Koperasi KPRI Mekar Barat Sadananya Ciamis.

Analisis Perputaran Piutang dalam Meningkatkan SHU Pada KPRI Mekar Barat

Untuk mengukur peranan variabel perputaran piutang $(\mathrm{X})$ dalam meningkatkan SHU (Y) terlebih dahulu dihitung nilai $r$, data-data perhitungan tersebut bersumber dari tabel berikut:

Tabel 7

Perhitungan korelasi Product Moment Pearson Perhitungan variabel X \& Y

\begin{tabular}{llllll} 
Tahun & $\mathrm{X}$ & $\mathrm{Y}$ & $x^{2}$ & $y^{2}$ & $\mathrm{xy}$ \\
\hline 2014 & 1,61 & 29,10 & 2,60 & 846,81 & 46,85 \\
2015 & 1,67 & 11,00 & 2,79 & 121,00 & 18,37 \\
2016 & 1,57 & 23,17 & 2,46 & 536,85 & 36,38 \\
2017 & 1,21 & 27,14 & 1,46 & 736,58 & 32,84 \\
2018 & 1,11 & 44,80 & 1,23 & 2007,04 & 49,73 \\
\hline$\Sigma$ & 7,17 & 135,21 & 10,54 & 4248,28 & 184,17
\end{tabular}

$r_{x y}=\frac{n \cdot \Sigma \mathrm{XY}-(\Sigma \mathrm{X})(\Sigma \mathrm{Y})}{\sqrt{\left[n \Sigma \mathrm{X}^{2}-(\Sigma \mathrm{X})^{2}\right]\left[n \Sigma \mathrm{T}^{2}-(\Sigma \mathrm{Y})\right]^{2}}}$

$r_{x y}=\frac{5.184,17-(7,17)(135,21)}{\sqrt{\left(5.10,54-(7,7)^{2}\right)\left(5.4248,28-(135,21)^{2}\right)}}$

$r_{x y}=\frac{920,85-969,46}{\sqrt{(52,70-51,41)(21241,40-18281,74)}} r_{x y}=\frac{-48,61}{\sqrt{(1,29)(2959,66)}}$

$r_{x y}=\frac{-48,61}{\sqrt{3817,96}} r_{x y}=\frac{48,61}{61,79} r_{x y}=0,79$

Untuk mengukur besarnya peranan perputaran piutang dalam meningkatkan SHU. Menggunakan rumus regresi linier sederhana.

$\gamma=a+b x$ 
Dimana nilai a dan $\mathrm{b}$ dapat dicari dengan menggunakan rumus sebagai berikut:

$$
\begin{aligned}
& a=\frac{(\Sigma \gamma)(\Sigma \chi)^{2}-(\Sigma \chi)(\Sigma \gamma)}{n \cdot \Sigma \chi^{2}-(\Sigma \chi)^{2}} a=\frac{(135,21)(7,17)^{2}-(7,17)(184,17)}{5.10,54-(7,17)^{2}} \\
& a=\frac{6951,15-1320,50}{1,29} a=4364,84 \quad b=\frac{n \cdot \Sigma \chi \gamma-(\Sigma \chi)(\Sigma \gamma)}{n \cdot \Sigma \chi^{2}-(\Sigma \chi)^{2}} \\
& b=\frac{5 . .184,17-(7,17)(135,21)}{5.10,54-(7,17)^{2}} b=\frac{920,85-969,46}{1,29} b=\frac{-48,61}{1,29} \\
& b=37,68
\end{aligned}
$$

Jadi persamaan regresi liniernya adalah:

$$
\gamma=4364,84+37,68
$$

Dari persamaan regresi tersebut dapat diuraikan sebagai berikut:

a. Jika tidak ada peranan dari perputaran piutang maka besarnya SHU pada KPRI Mekar Barat Ciamis sebesar 4364,84

b. Setiap terjadi penambahan peranan perputaran piutang sebesar 1 (satu), maka peningkatan SHU pada KPRI Mekar Barat Ciamis bertambah sebesar 37,68.

Uji t

$t=\frac{r \sqrt{n-2}}{\sqrt{1-r^{2}}} t=\frac{0,79 \sqrt{5-2}}{\sqrt{1-(0,79)^{2}}} t=\frac{0,79 \sqrt{3}}{\sqrt{1-0,62}} t=\frac{0,79.1,73}{0,38} t=\frac{1,3667}{0,38} t=3,597$

thitung sebesar kriteria 3,597 pada $\mathrm{dk}=(\mathrm{n}-2)=(5-2)=3$ dan $\alpha=0,05$, sedangkan $\mathrm{t}$ tabel adalah 3,182. Dengan demikian maka t hitung $(3,597)>$ dan t tabel $(3,182)$ ini berarti $H_{o}$ ditolak dan $H_{i}$ diterima. Jadi hipotesis yang diajukan diterima, yaitu tingkat perputaran piutang berperan secara signifikan dalam meningkatkan SHU.

\section{KESIMPULAN}

Berdasarkan hasil pembahasan yang telah dilakukan, maka dapat diambil beberapa kesimpulan sesuai dengan permasalahan yang diteliti, sebagai berikut :

1. Perputaran piutang pada KPRI Mekar Barat Sadananya Kabupaten Ciamis selama 5 tahun yaitu, tahun 2014 sebanyak 1,61 kali, 2015 sebanyak1,67 kali, tahun 2016 sebanyak 1,57 kali, tahun 2017 sebanyak 1,21 kali dan tahun 2018 sebanyak 1,11 kali, hal ini berarti perputaran piutang pada koperasi Mekar Barat sudah baik, dan waktu perputaran piutang relatif cepat.

2. Besarnya peningkatan laba usaha pada KPRI Mekar Barat Sadananya Kabupaten Ciamis untuk waktu 5 tahun yaitu tahun 2014 SHU sebesar 29.100.000, pada tahun 2015 sebesar 11.000.000, pada tahun 2016 sebesar 23.169.426, pada tahun 2017 sebesar 27.142.000, dan pada tahun 2018 sebesar 44.798.000. Pada tahun terakhir mengalami kenaikan SHU 33,13\% berarti koperasi tersebut lebih baik dari tahun sebelumnya cara mengelola usahanya terutama dalam pengelolaan piutang anggota.

3. Besarnya peranan perputaran piutang dalam meningkatkan laba pada KPRI Mekar Barat Sadananya Kabupaten Ciamis yaitu 37,68 $\%$ sedangkan $62,32 \%$ peranan diberikan oleh faktor lain.

\section{DAFTAR PUSTAKA}

Arikunto, S. 2010. Prosedur Penelitian Suatu Pendekatan Praktik. Jakarta: Rineka Cipta. 
Munawir, S, (1995). Analisa Laporan Keuanga. Liberty. Yogyakarta.

Munawir, S. (2004). Analisa Laporan Keuanga. Yogyakarta:Liberty.

Sugiyono. (2011). Metode Penelitian Kuantitatif, Kualitatif dan R\&D. Bandung: Afabeta.

Syamsuri, S.A. (2002). Kapita Selekta Koperasi. Bandung: Pustaka Bina Esa. 
